INÉDIT

\title{
REFLECTIONS ON THE HISTORY OF SCEPTICISM
}

\author{
Richard H. POPKIN
}

I was most honored by the holding of a Journee Richard Popkin in January 1997 about my work on the history of scepticism. For health reasons I was unable to attend the event, and was unable to discuss the papers with the participants. I have only seen drafts of three of the papers presented, and do not feel that I can comment on the session as a whole until I have a chance to see the finished papers, and to consider that various points made.

It was very touching to me that the Journée Richard Popkin was held at the centre Alexandre-Koyré. Professor Koyré played a most important role in my development as a scholar of the history of ideas. He was teaching at the École libre des hautes études in New York during World War II, when I was a student at Columbia University. He presented a paper at the Columbia Philosophy seminar, and he attended other meetings there. We met, and he took a great interest in what I was doing. As I began publishing on the history of scepticism, I sent him my papers, and he always responded with helpful and encouraging advice. I think he was one who encouraged me to apply for a U.S. Fulbright Research Grant to study in Paris, and he must have written a strong recommendation, since I was awarded the grant in 1952 (the competition to do research in Paris was very great then). When I arrived in September 1952, Koyré introduced me to many French scholars who were most helpful in advising me, in discussing my ideas, and in steering me to relevant materials. It was through Koyré that I got to know many of the leading active scholars in Paris. I was also invited to participate in the meetings on the history of science that took place at the Hôtel de Nevers next door to the Bibliothèque nationale. In 1956 when I returned again to Paris, we lived near the Jardin des plantes on the rue Linné. Many times I would stop by Koyré's apartment on the rue de Navarre to discuss my latest ideas. We continued these discussions whenever I was in Paris thereafter until his death. In the 1960's I also began working on Jewish history, which I also discussed at length with Koyré. He seemed not to share Revue de synthèse : $4^{\mathrm{e}}$ S. $\mathrm{n}^{\text {os }}$ 2-3, avr.-sept. 1998, p. 323-338. 
my enthusiasm for the subject, so I was surprised to learn much later on after his death, that he too was working on the same subject.

Much of my book, The History of Scepticism, was researched in Paris in 1952-1953. For most of the year we lived in an apartment on the rue de Richelieu which gave me the unfair advantage over other scholars of being able to get out of bed, rush down to the Bibliothèque nationale, get a seat assignment, order some books, and then go home to have a leisurely breakfast before beginning the assault on the treasures of the history of scepticism. Besides learning the arcane secrets of the library, I soon met many of the active scholars of the time with whom I was able to discuss my interests and researches. Koyré introduced me to Henri Gouhier, Robert Lenoble, Bernard Rochot, Father Julien-Eymard d'Angers, René Pintard, Jean Orcibal, Jean Jacquot, and many others who freely and generously gave of their time to discuss my researches and my overall hypothesis that the revival of ancient scepticism in the 16th century played a vital role in the development of modern philosophy. Father Paul Henry, S.J., the great Plotinus expert, who I had met during his first visit to the United States, also was most helpful in launching me into the French intellectual world.

I ransacked the Bibliothèque nationale, and some of the other libraries in Paris. I had started out with a theory that modern philosophy developed out of a sceptical crisis engendered from the rediscovered texts of Sextus Empiricus in the 16th century, their absorption by Montaigne into a modern critique of knowledge claims that challenged previous theories and forced thinkers from Bacon and Descartes onward to try to overcome this sceptical challenge. My theory, as far as I can recall, emerged from a seminar I took at Yale in 1946 on David Hume. I wrote a paper on Hume and Sextus for my course project. I had earlier encountered Sextus when as a sophomore at Columbia I took John Herman Randall's famous course on the history of philosophy. As a callow youth of 17, I was introduced to Plato and Aristotle, whom I was too young to appreciate or understand. A couple of weeks later in the course we were assigned to read Sextus. I recall reading the Loeb Library edition on the subway going home to The Bronx and being enthralled. I had found a philosopher who meant something to me. A couple of years later I took the first seminar Paul Oskar Kristeller gave in America, on post-Aristotelian Greek philosophy. The Stoics, the late Platonists, etc. did not excite me, but finally we came to Sextus, and again I was enthralled.

So, I wrote my paper on Sextus and Hume, and I showed it to Kristeller. He looked it over carefully and said to me in his most scholarly fashion : "You should find out if there was any sceptical tradition connecting Hume with Sextus. Was there any sceptical tradition in European philosophy before Hume? » So, I had my mission. 
When I began teaching at the University of Iowa a couple of years later, I was invited to give a paper on my research to the local Humanities Society. In 1951 I presented a paper on « The Sceptical Crisis and the Rise of Modern Philosophy ", displaying a whole sceptical tradition from the revival of Sextus in the 1560's to Montaigne, and then following this down to Hume. I sent the paper to another teacher, Paul Weiss of Yale, who was the editor of the new Review of metaphysics. He had already published a paper of mine on Berkeley and Pyrrhonism, and another on Hume and the Pyrrhonian controversy. He told me he would publish my paper if I footnoted every author and every book mentioned. The article ended up a three part exposition with well over two hundred footnotes, published in 19531954. Looking at the articles now, I am amazed that I could have put together so much of the story from materials in the University of Iowa library, and a few visits to the Newberry Library in Chicago...

What was lacking, and what $I$ found in my first Paris sojourn, was a context. Why was there a sceptical crisis in the 16th century, and why did this have such a prolonged effect on European thought? How did the philological revival of Sextus interact with the religious and scientific concerns of the Renaissance, the Reformation and the Counter-Reformation?

The history set forth in my book, written during the next years after returning to the United States, broadened and enriched by another visit to Paris in 1956, and with another year as Fulbright Research Professor in Utrecht in 1957-1958, showed how ancient sceptical problems came to life again in the great religious quarrels of the time, how the ancient sceptical problems applied to the theological debates of the time, to the quest for an indubitable criterion of religious knowledge, to the undermining of Scholaticism, and finally to the attempt of René Descartes to find a basis of truth that no sceptic could attack.

Since the first publication of my book in 1960 , by the University of Utrecht series in the history of philosophy, I have broadened my perspective, carried it beyond Descartes to Spinoza, included various other thinkers in my story, such as the Cambridge Platonists, extended portions of my story up to Bayle and on to Hume, to various French Enlightenment figures, and to some of the people around Kant. I have also been working on what I call « The Third Force », a group of thinkers in the 17th century who were offering a more mystical and prophetic answer to scepticism.

I began to see the need to prepare a further version of my story, a final one, connecting the original story with a quite different one, the use of scepticism as a basis for prophecy. Building on some of the work of the late Charles B. Schmitt, I saw that the first real entry of the ideas of Sextus took place eighty years before Montaigne read Sextus, in Florence, in the Convent of San Marco, where Savonarola in 1497-1498 asked some of 
his monks to prepare a Latin edition of Sextus. At the time there were more manuscript copies of Sextus's writings in San Marco than in any other place in the European world.

A paper of mine, "Scepticism and Prophecy », dealing with this appeared in the British Journal of the history of philosophy (41, 1996, p. 1-20). Having written the article, I realized the need to prepare a new edition of my book, and I am now committed to telling the story of the history of scepticism from Savonarola to Pierre Bayle's article on « Savonarola » in the Dictionnaire historique et critique (1695-1697). Oxford University Press will be the publisher of this revised edition of The History of scepticism, which I hope to complete in 1999 or 2000.

Schmitt had written on the first presentation of Sextus's ideas in 1520 by Gianfrancesco Pico della Mirandola, a nephew of the great humanist. The younger Pico was a close follower of Savonarola. His book used Sextus's arguments to demolish Aristotelianism and pagan philosophy in general in favor of accepting prophetic faith. Schmitt had said that Pico's work had practically no influence. However, following up on some of the detective work of Luciano Floridi about who read Sextus at the time, I not only realized that Sextus's text was widely known in Savonarola's day, and that Pico's exposition was probably what Savonarola wanted - scepticism used to eliminate pagan philosophy in order to open the road for prophetic knowledge. I found that a Venetian rabbi around 1620 was using both Pico and Sextus to justify knowledge based on the Torah alone.

Further, that the sort of view offered by Pico and Savonarola represents a quite different tradition from that of Montaigne and the French sceptics, and is a tradition that reappears, perhaps not directly from its earlier versions, in thinkers like Jan Amos Comenius, Joseph Mede, John Dury, and a host of Third Force thinkers. Occasionally the two histories of scepticism met as when Descartes, working on the Discours de la méthode met Dury who was working on finding a basis for certainty in Scripture prophecies, and when Descartes had a summit conference with Comenius. Descartes decided that Comenius did not know enough mathematics to find certainty, and Comenius decided Descartes did not know enough about Biblical prophecies to find certainty. The Third Force people, Henry More, Ralph Cudworth, Isaac Newton, accepted Pyrrhonian scepticism as a way of rebutting new dogmatists like Descartes, while using religious and spiritual sources as a basis for their certain knowledge. This tradition was flourishing into the 18th century, with its best expression appearing in the work of Hume's patron, Chevalier Andrew Michael Ramsey, the leading Scottish Catholic of the time and Grand Master of the French freemasons. Ramsey used Pyrrhonism as the way to lead people to realize that knowledge can only be gained mystically. Hume used some of Ramsey's material in his Treatise of 
human nature but left out the mysticism. Ramsey's way probably continued in mystical writers from Swedenborg to Madame Blavatsky, a portion of this second history of scepticism that needs to examined.

Pierre Bayle's article on «Savonarola » is intriguing as a blunt way of separating the good guys, the sceptics in the Montaigne tradition, from the bad ones, Savonarola and the Millenarian mystics. Bayle in this article dropped all pretense of objectivity, and just denounced Savonarola as a fake and a fraud who deserved the tortures inflicted on him in order to make him admit his dishonesty. Bayle, in other articles, bitterly attacked Comenius, Joseph Mede, John Dury, Pierre Jurieu, and other prophetic millenarians as wild-eyed dreamers and madmen. Later, this line of sceptics stemming from Montaigne could find little in common with those who took the mystic religious turn.

I would just like to present some of what I plan to advance in this revised History of scepticism, plus some indications of other matters in the later history of philosophy up to the present that still need to be incorporated into a full blown history of modern philosophy as the ongoing dialectic of scepticism versus dogmatism.

Many scholars, some students of mine, some associates in various projects, have been following out aspects of the history of scepticism from the 16 th century onward. So much material had been presented that over a decade ago Schmitt and I decided that a conference ought be held about some of these new findings. The conference was held at Wolfenbüttel in 1985. After Schmitt's sudden unexpected death, two conferences were held at the Warburg Institute in which further aspects of scepticism were presented. I started presenting the materials from the archives of the Amsterdam Synagogue raising sceptical problems about Christianity, materials that became a vital part of the Enlightenment critiques of revealed religion. In Amsterdam, Jews forced to convert in Spain and Portugal who had studied in Catholic universities, now felt free enough to write, but not publish, arguments that Christianity was not the true religion. These manuscripts circulated widely, and entered the general Christian world when some were auctioned off in The Hague in 1715. Their sceptical views about Christianity were known to John Locke, to Voltaire, to Anthony Collins, to Baron d'Holbach among others (d'Holbach actually printed extracts from Orobio de Castro, entitled Israël vengé). These materials were regarded as the strongest reasons for doubting Christianity. Around 1800, an American preacher found one of these manuscripts in the basement of the Harvard library, and was so startled he took it to the rabbi of New York for elucidation. He then published a disproof of Christianity, rushed to the Middle East, put on a fez and became a Turkish spy!

In addition to the Jewish anti-Christian materials as bases for scepticism, another source of doubts was the interest in the ancient life of Apollonius 
of Tyana, a pagan of the Hellenistic period who lived a parallel life to that of Jesus of Nazareth. He had a miraculous birth, performed miracles, etc. His followers formed a new religion waiting for his return to earth. In the 17th century the sceptical problem was raised, how does one tell if Jesus was divine and Apollonius was not? Or if one cannot, then... The English deist, Charles Blount, published part of the Life of Apollonius in English, and in the footnotes presented a dialogue between a Jew and a Muslim, expressing their inability to discern any difference in these cases. The same debate also resulted from the messianic career of Sabbatai Zevi, a Turkish Jew who proclaimed himself the Messiah in 1666, and then recanted and became a Moslem. Over $90 \%$ of the Jews in the world first accepted him, and then renounced him. So, as some doubters suggested, the Jews lacked a criterion for telling a true Messiah from a false one, and as Voltaire developed the case, everyone else is in the same fix.

A much circulated manuscript of the late 17th century, Les Trois Imposteurs, Moïse, Jesus et Mohammed, ou l'esprit de M. Spinosa, used ammunition from Hobbes, Spinoza and La Mothe Le Vayer, to cast doubt on the entire revealed religious tradition. Considerations of materials like these led to a further conference in 1990 at Wassenaar in The Netherlands on scepticism for and against religion in the 17th century, a conference sponsored by the Foundation for Intellectual History of London.

I had been exploring ways in which the revived Pyrrhonian tradition in the 17th century was used to advocate accepting religion on faith alone, and on the other hand how defenders of normal orthodoxy found that they had to deal with Sextus before treating the religious and irreligious issues of the day. An English theologian actually felt he had to resolve sceptical problems from Sextus before refuting a claim of the time that there could be two Messiahs rather than just one.

The French sceptic, François de La Mothe Le Vayer, had labelled the ancient Pyrrhonian author, "le divin Sextus", the author of our new Decalogue (the ten tropes). La Mothe Le Vayer, whether sincerely or not, claimed the true sceptic like himself should leave his doubts at the foot of the altar, and accept what God reveals to us on faith alone.

Another indication of how Sextus was immersed in the philosophicaltheological thought of the 17th century, appears in Ralph Cudworth's massive The True Intellectual System of the Universe, of 1678, Cudworth kept discussing two personnages, Sextus the philosopher, and Sextus Empiricus. The latter is the source of a lot of information about ancient philosophy. The former shows the failure of atheistic dogmatism to disprove the existence of God.

Pyrrhonian scepticism was known, used, discussed, in almost every intellectual context in the 17th century. Sextus's Pyrrhonian Hypotyposes 
was translated into English by Thomas Stanley in his History of philosophy (1655). Samuel Sorbière was preparing, but did not finish a French translation at the same time. A French translation of the Hypotyposes did appear in 1725, reprinted in 1735, and a French version of part of Adversus Mathematicos appeared in 1779. A German edition was published in 1801. Sextus's text was known and used by almost all thinkers of note in the period. Copies of his text in Latin and Greek appear in large numbers of library collections.

There were a very large number of ways people could have come across Sextus's arguments in addition to reading existing texts and translations. Gassendi and Bayle presented a lot of Sextus's materials. Bishop PierreDaniel Huet, of Avranches, in his Traité de la foiblesse de l'esprit humain of 1721, summarized the content of Sextus, defended him against critics ancient and modern, and contended that the perennial philosophy was actually scepticism, and that Maimonides, Averroes and St. Thomas were all part of the sceptical tradition going back to antiquity and then flourishing in the Royal Society of England. Huet's Traité was translated into Latin, English, German, and Italian.

An opposition work, the Examen du pyrrhonisme by Jean-Pierre Crousaz, a really massive attack on Sextus, Bayle and Bishop Huet appeared in 1733.

At the first International Congress on the Enlightenment held in Geneva in 1963, I gave a paper on "Scepticism in the Enlightenment ", in which I indicated how prevalent knowledge of and interest in scepticism was in the beginning of the 18th century. Then I claimed that except for the writings of David Hume, scepticism died out as a major philosophical current. The philosophes were too positive. It was only when Hume awoke Kant from his dogmatic slumbers that scepticism again gained center stage. One of the auditors, my late friend, Giorgio Tonelli, set to work developing a new perspective on scepticism in the Enlightenment in which he contended that a central theme of many of the philosophes was actually the weakness of reason rather than the authority of reason. In a series of papers on various leading figures in France and Germany, Tonelli showed that there was a basic scepticism about the possibility of any metaphysical knowledge, a recognition of the limits of knowledge of any extramental reality based on our faculties, and a need to accept limited certitude in the sciences. The late Ezequiel de Olaso of Buenos Aires carried this analysis into the scepticism expressed by Jean-Jacques Rousseau in the views of the Savoyard Vicar in Émile. Subsequently Keith Baker showed that Condorcet also fell into this group of sceptical philosophes, and that Condorcet's probabilism partly resulted from his direct knowledge of David Hume's Treatise of Human Nature in English. 
In two forthcoming papers for the Cambridge History of 18th-Century Philosophy I present this new appreciation of the kind of scepticism that appeared from $1750 \mathrm{on}$. And I added to the material the finding that Jacques Pierre Brissot de Warville, who became the leader of the Girondins during the French Revolution, had tried to interest D'Alembert in preparing an Encyclopédie du pyrrhonisme. D'Alembert refused, but I found, thanks to leads from my son Jeremy and others, that a manuscript of part of this by Brissot exists, and that he had published a large book in 1782, reissued in 1792 (shortly before Brissot was guillotined) showing how very little can be known in any of the sciences. At the end Brissot had said he hoped to be able to compile a list of the few truths in the near future when he finished some political projects.

The secular scepticism of both Brissot and Condorcet (who worked together on many liberal causes during the Revolution) no longer involved any compromise or co-existence with religious views. They were advocates of a limited scepticism based on empirical studies and probabilities, studies which could be used for the betterment of the human condition in a scientific world freed of all religious trappings and authoritarian controls.

Because so much had been developed by scholars about 18th-century scepticism, a conference I helped design on scepticism at the end of the 18th century was held in 1996 at Göttingen and Leipzig, and included many studies about what happened in France, England, Scotland and Germany. The papers have recently been published in a volume, The Sceptical Tradition around 1800, edited by Johan Van der Zande and myself (Dordrecht, Kluwer, 1998).

A centerpiece of this conference was some papers about a much neglected text, Geist und Geschichte des Skepticismus by the Göttingen professor, C. J. Stauidlin of 1794. Staüdlin was a close friend of Kant. His history, unlike mine, covered everything from Pyrrho to Hume and Kant. The work, which is in the process of being translated into English now, is a marvel in giving the flavor of the sceptical crisis of the late 18th century in Germany, and in giving a sceptical reading to Kant's endeavor to overcome scepticism through transcendental philosophy. Staüdlin treated Kant as a sceptic malgré lui, who had failed to establish any objective knowledge. Still Staüdlin felt that he and Kant could work together as practical sceptics in advocating freedom of speech, press, limited religious control, etc.

Looking at the end of the century through Staüdlin rather than Kant opens many doors that now need exploration. A German translation of Sextus by Johann Gottlieb Buhle appeared in 1801. John Laursen and I have discovered a hitherto unknown French translation of part of Sextus's Adversus Mathematicos in 1779 in Berlin, and later reprinted in Paris, by a member of the Prussian Academy. An account of this will appear this year 
in the British Journal of the history of philosophy. Many intellectuals actively involved in the post-Kantian world were either pushing Kant into scepticism, or were offering a scepticism against Kant. Solomon Maimon, Schulze-Aenisedemus (reviving the arguments that are the basis for Sextus's work), Hölderlin and others were involved in this.

So, I think we now know that a resurgence of scepticism occurred in the late 18th century in Germany. Much remains to be done in following this out in the early 19th century. Thinkers like Karl Marx and Søren Kierkegaard were much influenced. Marx was originally intending to follow up his dissertation on Epicureanism with a study of ancient scepticism. Kierkegaard drew upon the full force of Pyrrhonism in Sextus and Bayle in his attack on the "comedy of the higher lunacy », the attempt to establish a rational basis for belief in the existence of God. As Jose Maia Neto has shown in the recent Christianization of Pyrrhonism, Kierkegaard made the totally irrational existential leap into faith the only way beyond complete scepticism.

A few years ago I came across a curiosity that needs further exploration, namely that in 1843 the French Academy of Moral Sciences proposed a prize essay contest on whether there is any basis for certainty. The participants were told that they should discuss Sextus Empiricus, Bayle, Bishop Huet and Hume in their answers. There were apparently many submissions. The winning answer, according to Adolphe Franck, was by an A. Javary, who said that his teacher, Victor Cousin, had found the basis of certitude. He applied his teacher's views to the problems raised by sceptics ancient and modern. It would be interesting to find and examine the rest of the submissions, as an indication of how seriously the sceptical challenge was taken at the time. Javary dealt with the religious use of scepticism of Lamennais and de Bonald among other topics.

A little later on the other side of the Atlantic, Charles Sanders Peirce, the most original American thinker of the time, was studying Sextus Empiricus in the Harvard Library. Fortunately Harvard still has the call slips from the time, and one can tell exactly when Peirce was using Harvard's copy of Sextus.

I am sure there are many more cases to be studied amongst 19th-century thinkers from the English idealists, from Nietzsche, from the American pragmatists, from French thinkers like Charles Renouvier, etc.

I rarely get into the heady world of 20th-century thought in my researches. But $I$ have run across some odd and amazing appearances of Sextus that cry out for further exploration and explanation. It was obvious that Ludwig Wittgenstein read Sextus since some of the aphorisms in the Tractatus are taken from Sextus's text. Moritz Schlick in his first writings on logical positivism was struggling to overcome Hume's scepticism with 
regard to reason. George Santayana, in his Scepticism and animal faith, presented a naturalistic and mystical version of Pyrrhonism.

A few years ago in Amsterdam there was an exhibit at the Stedeliche Museum about Oskar Schlemmer, one of the founders of the Bauhaus. In the exhibit which had all sorts of contributions by Schlemmer, there was a copy of his opening lecture in the Bauhaus. On the first page he began with a discussion of Bayle and Sextus! So there is need to explore scepticism and the Bauhaus movement.

When I began working on the history of scepticism I found that a French translation of Euvres choisies of Sextus had appeared in 1948 (Paris, Aubier Montaigne), done by Jean Grenier and Geneviève Goron. It included the Pyrrhonian Hypotyposes and parts of Adversus Mathematicos. Grenier had also written on La Mothe Le Vayer and the character of 17thcentury literary scepticism. I had been in correspondence with Grenier before I went to France in 1952. He had been a professor in Algiers and in Cairo, and had written many literary works indicating his interest in eastern thought, the human condition, etc. When I got to France, we had several discussions at his Sunday afternoon philosophical-literary gatherings. Grenier had been the teacher of Albert Camus. At his gatherings we met Cioran who had recently appeared on the French scene. So, there is at the very least a suggestion that concerns with Pyrrhonism were related to the exploding existentialist world of the time.

A few years ago I asked Kristeller why he devoted two out of fifteen sessions of his course on Post-Aristotelian Philosophy to Sextus. I knew Kristeller had no sympathy for the sceptical outlook, and was a firmly convinced Neo-Kantian. The course, given at Columbia in 1944, had just two students. It was the first course Kristeller gave in the United States (and has recently appeared as a book, Greek Philosophers of the Hellenistic Age, New York, Columbia University Press, 1993). Kristeller stood at a lectern, and proceeded to lecture for about an hour and a half. Then he stopped and asked the two of us if there were any questions. We were given enormous bibliographies, the basic known facts about the ancient philosophers, a careful presentation of their arguments, and an assessment of their influence. When I asked a few years ago why there was so much on Sextus, Kristeller calmly told me that the lectures he gave us were from the lectures he had received from his teacher, Martin Heidegger! So why did Heidegger care so much about Sextus?

A last tantalizing item I learned about in 1992 is that Sextus was translated into Russian in 1975-1976. A two volumes edition appeared including the Pyrrhonian Hypotyposes and Adversus Mathematicos, put out by the Soviet Academy of Sciences in 200000 copies. The translator was Aleksei Fedorovich Losev, a classical scholar who had worked on Plotinus, on a translation of Plato, and on the Russian mystic, Solovyov. Losev died 
recently at the age of 101 . There is no indication he had any troubles with governmental authorities throughout his long career.

Sextus in Russian in 1975-1976! Who read it? What did they make of it? I have gotten a few tantalizing hints from a present member of the Russian Academy of Sciences, who told me that the work was very well received, and that it had much influence. Beyond that I have not been able to get any specifications. When I asked if the work might have played a role in what happened under Gorbachev, the response was "Yes ». A former student of mine was able to purchase a fresh copy of the edition for me in Moscow just a few weeks ago. I have been told there is evidence that Sextus has been known to Chinese scholars too.

It is curious that Sextus has appeared in so many editions, and translations, and has had so many effects, yet it has never been banned or put on the Index even apparently in Communist Russia. There was no suggestion during the Counter-Reformation that it should be banned, and, of course, the chief 16 th-century edition was by the secretary of the Cardinal of Lorraine, Gentian Hervet, who used the Cardinal's own manuscript of the Greek text.

The works of Sextus have played a monumental role in the history of philosophy since the early 16th century. It was claimed by Alfred North Whitehead that the whole history of philosophy is just footnotes to Plato and Aristotle. I think by now one has to amend this and add footnotes also to Sextus, to Cicero, perhaps to Plotinus, and maybe the Stoics as well. Footnotes to Sextus dominate the development of philosophy in the last 450 years. Sextus's terminology, as translated by Montaigne and Francis Bacon, is the language of philosophy ever since. Sextus's arguments have been at the center of what has been argued from Descartes to the end of the 20th century. Over and over again scepticism is refuted, then turns up on another front endangering any claims to genuine knowledge that cannot possibly be false. The dialectic of the modern historical drama in philosophy has been sceptical attacks on dogmatisms, and dogmatic attempts to answer, defuse or evade, the sceptical attacks. In the last fifty years, at least in Anglo-American philosophy, we have moved from a stage where practically nothing was published about Sextus or scepticism to where every journal in every issue has more and more articles about scepticism. When I started out the only article in English on Sextus was one by Roderick Chisholm, the first paper he ever published. The Loeb Library edition was still incomplete. And now several new translations of Sextus have appeared and scepticism is a hot button issue. Many scholars of ancient philosophy like Myles Burnyeat, Julia Annas, Jonathan Barnes, Benson Mates, Dorothea Frede, Michael Frede, and others, are constantly broadening our knowledge and understanding of classical sceptical texts. 
In a book that has recently appeared Sketches and landscapes. Philosophy by example (Cambridge, MIT Press, 1998), my friend, collaborator and sometime colleague, Avrum Stroll, starts out arguing that contemporary philosophers have misunderstood the role the history of scepticism has played in philosophical discussions. He contends that contemporary analytic philosophers have failed to come to grips with scepticism because they fail to see how imbedded it is the philosophical scene. In explicating this, Stroll insists, rightly, that the ancient and modern sceptics and their dogmatic opponents agree about what knowledge is or would be, and are disagreeing about whether there is any actual knowledge. The facile refutations from the 17th to the 19th centuries fail to see this point, and hence fail to come to grips with the force of scepticism in philosophy. From ancient times when the Stoics were answering the Sceptics by saying that their position could not be stated without contradiction, dogmatists have thought it sufficient to brush off the sceptics by ad hominem arguments. Stroll contends that this avoids the deep serious challenge of scepticism to any dogmatic philosophy. The sceptics are parasitical on the dogmatists' position, accepting its framework and then attacking it with sceptical arguments. In so doing, the sceptics accept pro tem the dogmatist's conception of « knowledge ». It is then up to the dogmatist to try to answer the challenge within that conception.

I agree with Stroll that this characterizes most of what has been put forth as answers to scepticism from Descartes, Locke, Kant onward. However, I think there is a kind of « irrational » scepticism that is appearing at the end of the 20th century that no longer shares a common notion of « knowledge » with its opponents, and seems to be leading outside and maybe beyond the dialectical engagement of scepticism and dogmatism into some kind of nihilism.

Two radical different views have appeared in the late 20th century, one theological and/or religious, the other postmodern naturalist, that reject any fixed knowledge framework to argue about.

The first of these views is strongly presented by the founder of Christian Reconstructionism, Rousas J. Rushdoony, an Armenian American theologian, born in New York in 1916, from a family that had just escaped from the Armenian Holocaust. His father became a moderate Calvinist minister in California; Young Rousas Rushdoony went to the University of California, Berkeley. In a philosophy course with Edward W. Strong, a philosophical naturalist (later chancellor of the Berkeley campus in the early 1960's), he came to realize that one had to start with a « given » and could not prove or justify this starting point. He was also much influenced by the medieval historian, Ernst Kantorowicz, who made him realize the centrality of theology in politics and the state. After receiving both a B.A. and an 
M.A., and a theological degree from the Pacific School of Religion, Rushdoony became a missionary to the Indians in northern Nevada. It was there in 1946 that he came to know of the views of the strict Dutch Reformed thinker, Cornelius Van Til (1895-1987), professor at the Westminster Theological Seminary. Rushdoony accepted Van Til's view that Christianity was to be accepted without any presuppositions, since there was no standard or basis for arguing for or against Christianity. Accepting God as the source of all knowledge, the Bible was then accepted as the sole source of knowledge of God's views and teachings. This is developed in Rushdoony's first publication, By what standards (Philadelphia, The Presbyterian and Reformed Publishing Co., 1959), which uses the sceptical problem of the need for a criterion to justify knowledge, and to undermine other outlooks. The counter-view, scientific humanism, was what Van Til and Rushdoony called, « Bootstrap philosophy », the attempt by man unaided to lift himself up by his own bootstraps to achieve genuine knowledge of reality. Hume and Kant had adequately shown that this ends in subjectivism and doubt. This is developed in Rushdoony's The World of Flux (Fairfax, VA, Thoburn Press, 1975).

The critique offered by Van Til and Rushdoony of modem philosophy deserves a place in the history of scepticism in the 20th century. They used the sceptical arsenal of the sceptics ancient and modern to reveal that there is no foundation for enlightenment or rational philosophy, or for Christianity. Then they opted for knowledge as just Biblical statements. For Rushdoony this means a very extreme moral and political program. Civil law should be just Biblical law. Hence the secular education system, the banking system, and such are non-Biblical and must go.

Rushdoony expanded Van Til's unquestionable acceptance of the Bible as the source of knowledge to the acceptance of Biblical law as the sole source of social and moral law for mankind. Van Til felt Rushdoony went too far in using their Christian epistemology as a basis for a very conservative political program. Rushdoony rejects any secular basis for law. Natural law is just unwarranted secularism. The position Rushdoony developed in his many writings is that the acceptance of the Bible as the sole source of law was lost during the long domination of the Church of Rome. Calvin brought the Bible back to the center of religious thought, but Calvin still accepted a form of scholastic natural law theory, allowing for states to have civil laws based on other sources than Scripture. The 17th-century New England Calvinists set forth the true Biblical view. They covenanted with God and accepted God as the sole authority for the laws of their societies. This view was gradually eroded by the force of secularism and deism in the late 17th century and during the next century. By 1776 the God centered society was disappearing, replaced by man centered societies, which have been morally decaying ever since. Rushdoony totally rejects the Enlight- 
enment, and most of the intellectual foundation of the United States government, since it reflected leading secularist theories of the time. The real America was and is the covenanted colonial society. Everything else was illegimate, and should be replaced. He presented his case in a series of books appearing from the early 1960's, laying out the rejection of the entire Enlightenment, and of the secular American state, detailing the legitimate Biblical oriented state [of the Calvinist colonies] that should replace the amoral, decadent humanist society in America and the world.

The combination of scepticism and Biblicism appears in the writings of one of Rushdoony's European followers, Jean-Marc Berthoud, of the Creation Research Center of Lausanne, Switzerland. In his interesting essay, «Les différentes formes de causalité et la pensée de la Bible » (Positions créationnistes, $\mathrm{n}^{\circ} 25,1996$ ), he uses materials from Van Til, Rushdoony and myself, among others, to develop his view. In a private communication to me he has thanked me for providing " une lumière indispensable ». Berthoud argues that the intellectual choice is either the atheism of modern science, or Biblical science.

In the early 1960 's, Rushdoony founded and fostered a movement called Christian Reconstruction, seeking to bring people back to the basic Biblical Christian teachings as he sees them. Berthoud is the leader of the «reconstruction chrétienne » movement, and edits its journal Résister et construire. His group is involved with a small, very conservative French Calvinist movement centered around Pierre Courthial in the south of France.

Rushdoony's movement in the U.S. is small, and unaffiliated with any institutional church. Christian Reconstructionism keeps splintering over disputes as to what the Bible ordains or does not ordain. It is however amazingly influential in setting the programs of various fundamentalist groups. There are a few members of Congress who press for parts of Rushdoony's Biblical agenda. I have no idea if the European movement has had as much success.

If Christian Reconstructionism employs the sceptical weapons to eliminate any form of knowledge other than Biblical knowledge, on the other extreme of the present intellectual world is a general collection of views called "postmodernism ", which accepts a basic scepticism about whether there can be any certain or objective knowledge, and then turns the quest for knowledge into examining the activities of various groups and individuals, that can only be examined in context as examples of how these groups and individuals behave. The knowledge claims can be deconstructed, shown to have sub-texts, which favor certain causes or groups. The modern sciences are vehicles by which various programmes are carried on by and for certain groups. 
Starting at least as far back as Nietzsche, who saw the intellectual world around him as the result of one group's will to power, thereby making other groups seem adherents of false or dangerous views, knowledge is seen as the expression of an ideology, not as the conclusion of rational and evidential inquiry. Several decades later Martin Heidegger wrote against the technocratic world around him again as a production of the power of certain forces and groups. Apparently Heidegger's early adherence to Nazism was for him a rejection of the prevailing liberal, humanistic, scientific outlooks. Knowledge was subjective, and could not be justified in evidential terms.

For Nietzsche and Heidegger and many other recent thinkers, the problem of knowledge as stated by Descartes is based on a false or inadequate appreciation of the human situation. The way the problem is posed, according to thinkers like Foucault, is in terms of what some powerful institutional groups want, in order to control. Such groups « define » what is madness, rationality, morality, etc. There is no certain or objective truth above and beyond these definitions by power groups.

In another presentation of the knowledge situation, Jacques Derrida portrays it as a relationship between signifiers, words, signs, sounds. One never gets outside of texts to find objective certainty. Examination and deconstruction can reveal levels and differences of meanings, intentions, etc., but not some reality above and beyond discourse.

Both Foucault's and Derrida's ways of examining knowledge claims take the question of what is true outside the traditional frame of reference of Western philosophy. A kind of super scepticism then takes over in which all sorts of psychological, sociological, linguistic, historical claims can be offered that are relevant for some individuals or groups, but set no standards for mankind in general. How much Foucault, Derrida, or other leaders in the postmodernist movement derive some of their position from scepticism, ancient and modern, needs to be studied.

Postmodernism encompasses a large variety of intellectual activities. In the United States these include a great deal of literary criticism, and a great deal of history of various disciplines, especially the history of the sciences. A serious effort needs to be made to see to what extent a conscious reliance of elements drawn from the history of scepticism play a role. I have seen cases where my work is used as a launching pad for investigations into the non-cognitive causes of certain intellectual developments. Since there can be no dogmatic basis for the sciences, therefore various cultural factors should be studied instead as possibly explaining various developments.

In fact a kind of super relativism is being made of some of these ways of looking at knowledge, that may verge on intellectual nihilism, since the traditional ways of dealing with doubt have been thrown out along with the 
traditional questions. Sextus could quietly explain how a sceptic lives and acts by following appearances, feelings, and customs. But the postmodern sceptic may have appearances, feelings and customs that are too subjective so that no one can finish her or his internal examinations.

Philosophical scepticism has been going on for two and half millenia, questioning various dogmaticism stances, set forth in a conceptual framework. If the framework is dissolved or rejected, then is the grand history of scepticism over. I doubt it very much. The human temptation to formulate postmodernist attitudes didactically (these views are taught and discussed), will generate questioning, and new forms of scepticism. The new forms may be quite different from those we are used to, may not even be recognizable from the perspective of Hellenistic based scepticism.

However, seeing late 20th century sceptical developments in terms of the long history of scepticism, and seeing how contemporary sceptical theological movements, and postmodern ones utilize, develop, and then transform some of the prior sceptical developments may help us see where we are, and where we may be going. As an unregenerate sceptic I can only end this discussion with the sage words that a friend of Hume's, Thomas Blacklock, wrote: « The wise in every age conclude, what Pyrrho taught and Hume renew'd, that dogmatists are fools. »

Richard H. PopkIN Washington University, St. Louis, and University of California, Los Angeles (avril 1998). 